\title{
PLAG1 and CYLD do not play a role in the tumorigenesis of adenoid cystic carcinoma
}

\author{
TSUTOMU DAA ${ }^{1}$, ITARU NAKAMURA ${ }^{1}$, NAOMI YADA $^{1}$, SHIGEKI ARAKANE $^{1}$, HARUTO NISHIDA $^{1}$, \\ KENJI KASHIMA $^{1}$, MASASHI SUZUKI ${ }^{2}$ and SHIGEO YOKOYAMA ${ }^{1}$
}

Departments of ${ }^{1}$ Diagnostic Pathology and ${ }^{2}$ Otolaryngology, Faculty of Medicine, Oita University, Oita 879-5593, Japan

Received October 29, 2012; Accepted January 31, 2013

DOI: $10.3892 / \mathrm{mmr} .2013 .1311$

\begin{abstract}
The pleiomorphic adenoma gene 1 (PLAG1) gene is activated in a subset of pleomorphic adenomas of the salivary gland by gene fusion. Germ-line mutation in cylindromatosis $(C Y L D)$, a tumor suppressor gene, causes familial cylindromatosis and Brook-Spiegler syndrome. In the present study, aberrations in PLAGI and CYLD were investigated in adenoid cystic carcinoma (ACC) of the salivary gland. Reverse-transcription PCR and PCR direct sequencing were performed to detect gene fusion of PLAGl and mutation of $C Y L D$ in 34 ACC tissues. No PLAGl fusion was detected in ACC. However, silent mutation of $C Y L D$ was detected in 2 cases of ACC, but no missense mutation was detected in ACC. These results suggest that PLAGI and CYLD do not play a role in ACC tumorigenesis.
\end{abstract}

\section{Introduction}

Adenoid cystic carcinoma (ACC), a relatively rare tumor occurring mainly in the salivary glands, is a slow growing but highly malignant tumor. In recent years, cancer treatment has shifted to molecular-targeted therapy based on molecular aberrations in specific neoplasms. The molecular pathology of ACC, however, has not been fully elucidated.

Pleiomorphic adenoma gene 1 (PLAG1) and cylindromatosis $(C Y L D)$ are genes known to affect tumorigenesis. PLAGI is commonly rearranged in a subset of pleomorphic adenoma (PA) of the salivary gland by chromosomal aberrations, resulting in gene fusion. Several fusion partners of PLAG1, including CTNNB1, CHCHD7, LLIR and LIFR, have been identified (1-7). PLAG1 protein is a zinc finger protein that functions as a DNA-binding transcription factor. Deregulated transcription of various genes by abnormally expressed PLAG1

Correspondence to: Dr Tsutomu Daa, Department of Diagnostic Pathology, Faculty of Medicine, Oita University, 1-1 Idaigaoka, Oita 879-5593, Japan

E-mail: daatom@oita-u.ac.jp

Key words: pleiomorphic adenoma gene 1, cylindromatosis gene, adenoid cystic carcinoma is hypothesized to play a major role in the development of PA. PA is the most common neoplasm of the salivary gland and shares specific morphological characteristics with ACC. ACC and PA tumors are composed of epithelial and myoepithelial cells. Ultrastructural analysis indicates that these tumors have a similar histogenetic basis (8). However, the role of PLAG1 in the development of ACC remains unknown. Matsuyama et al (9) analyzed two cases of ACC and identified no fusion genes involving PLAG1.

$C Y L D$ is a tumor suppressor gene, the germ-line mutation of which causes familial cylindromatosis and Brook-Spiegler syndrome (10). The gene encodes a cytoplasmic protein that functions as a deubiquitinating enzyme. CYLD protein plays a role in cell proliferation and survival by negatively regulating nuclear factor- $\kappa \mathrm{B}$ (11). There are morphological similarities between cutaneous cylindroma and ACC, and ACC was previously considered to be a cylindroma (12).

The present study was designed to determine the role of the $C Y L D$ gene in ACC of the salivary gland.

\section{Materials and methods}

Materials. A total of 34 paraffin-embedded blocks of ACC of the major and minor salivary glands were retrieved from the archival specimens maintained at the Pathology Center of Oita University Hospital (Oita, Japan). The study was approved by the ethic committee of Oita University, Faculty of Medicine.

Reverse-transcription (RT)-PCR. RT-PCR analysis for the detection of PLAG1 gene fusion was performed using the method described by Matsuyama et al (9) with minor modifications. RNA was extracted from formalin-fixed paraffin-embedded (FFPE) tissue using the Qiagen RNeasy FFPE kit (Qiagen, Hilden, Germany) according to the manufacturer's instructions. In brief, $10-\mu \mathrm{m}$ FFPE tumor sections of each sample were digested with proteinase $\mathrm{K}$ in lysis buffer. Total RNA adsorbed to the column provided in the kit was collected in the elution buffer. The extracted total RNA was reverse transcribed to cDNA using the First-Strand cDNA Synthesis kit (GE Healthcare, Tokyo, Japan).

In the present study, PLAGl-associated fusion transcripts with catenin $\beta 1(C T N N B 1)$, coiled-coil-helix-coiled-coil-helix domain containing 7 (CHCHD7), leukemia inhibitory factor receptor $\alpha(L I F R)$ and transcription elongation factor A (SII), 1 
Table I. Primers for RT-PCR.

\begin{tabular}{|c|c|c|}
\hline Primer designation & Sequence $\left(5^{\prime}-3^{\prime}\right)$ & Size of PCR product (bp) \\
\hline \multicolumn{3}{|l|}{ Reverse } \\
\hline PLAG1-exon 2R & gaccgtcacagaatgaagca & \\
\hline PLAG1-exon 3R & gccatgcccattgactcttc & \\
\hline \multicolumn{3}{|l|}{ Forward } \\
\hline CHCHD7-exon 1F & gtgagccattgacgtgtttg & 124 (with exon 2R), 123 and 228 (with exon 3R) \\
\hline$C T N N B 1$-exon $1 \mathrm{~F}$ & gaggaaggtctgaggagcag & 159 (with exon 2R), 158 and 263 (with exon 3R) \\
\hline$L I F R$-exon $1 \mathrm{~F}$ & agctcagaaagggagcctct & 105 (with exon 2R), 104 and 209 (with exon 3R) \\
\hline TCEAl-exon $1 \mathrm{~F}$ & gctttgccaagaagatggac & 106 (with exon 2R), 105 and 210 (with exon 3R) \\
\hline
\end{tabular}

PLAG1, pleiomorphic adenoma gene 1; CHCHD7, coiled-coil-helix-coiled-coil-helix domain containing 7; CTNNB1, catenin $\beta$ 1; LIFR, leukemia inhibitory factor receptor $\alpha$; TCEAl, transcription elongation factor A (SII), 1.

Table II. Primers used in PCR.

\begin{tabular}{|c|c|c|c|}
\hline Target & Forward & Reverse & Size of PCR product (bp) \\
\hline Exon 4-1 & tcttttgcggttttatgacaa & cggtactttaaggagcttttgtg & 199 \\
\hline Exon $4-2$ & tcaagaatgcagcgttacaga & agaactgcatgaggttgctct & 171 \\
\hline Exon 4-3 & gtggggcattcaaggattc & aggctgaacctctcctcaca & 173 \\
\hline Exon 4-4 & gcaacctcatgcagttctctt & tttcttcccagatctcagc & 194 \\
\hline Exon $4-5$ & aatagacgtgggctgtcctg & cagacacacatgaacacaaacaa & 187 \\
\hline Exon 5-1 & cccettttcctatggatcgt & ctttccaatgcagtgtcatca & 198 \\
\hline Exon 5-2 & agattgtggcgtgtttgttg & tcctggcaaaacatcacaga & 199 \\
\hline Exon 5-3 & tcgaacttcctcctttggaa & gatatttaatccaaaattttcttacca & 159 \\
\hline Exon 6-1 & tttggaggattctttatggaaaa & aacacacgcaaaactacaaagc & 151 \\
\hline Exon 6-2 & gggatggaagatttgatgga & aaccaaacaccacctgttcc & 188 \\
\hline Exon 7 & ctcaaatccactgtgggtga & accttaaagcccagcaatga & 190 \\
\hline Exon 8 & tttctcttctataagaatttgccttt & ggcattatgcaaattactaaaggtt & 198 \\
\hline Exon 9-1 & tttttaaatgaaacttttcttgttcc & tggattgtggttgtgagtcaa & 118 \\
\hline Exon 9-2 & ggatctacctcagaccctgga & tctgatgagttagaaagaaaggatca & 173 \\
\hline Exon 10-1 & gagtcaatatccttgaatacatttctg & attgggcatcttggtgagac & 194 \\
\hline Exon $10-2$ & accgttcttcaccaccactc & caagggtggactctcttgga & 194 \\
\hline Exon $10-3$ & attggccacagtccactttc & attcagtcctggtggctgac & 198 \\
\hline Exon $10-4$ & cctgggaactcacatggtct & gcgaaatctgcacaaaacct & 191 \\
\hline Exon 11-1 & ggcacggtataatgcatattga & gctgcaatgatgcaaaccta & 168 \\
\hline Exon 11-2 & gcgctgtttgtgaaactgaa & aaaacactgtcaccatcacctaa & 186 \\
\hline Exon $12-1$ & ttttgcatcaaaatacaaaaacatt & ctccaagccttctttttcca & 184 \\
\hline Exon $12-2$ & ttttcagcatttggaggcta & cctgcctcatggcactatct & 197 \\
\hline Exon 13 & gaaaattatcctttttcttttgcag & aggcaaaatagcaatttgttttc & 178 \\
\hline Exon 14-1 & tccagcctgagtgatagagtga & gatgcagcctccacctttt & 195 \\
\hline Exon 14-2 & tgtgtgccacaaaaattatgaa & ccccaactacacagacaca & 174 \\
\hline Exon 15 & tgatttaaaaattttgcctgtga & catgtctgttgaataatggcagt & 194 \\
\hline Exon 16-1 & ttaacattttgatttaagcatttga & cctctgcaaatttcaggttactg & 199 \\
\hline Exon $16-2$ & ttcccacaattcagcagttg & aagactcccacagactttcaca & 112 \\
\hline Exon 17-1 & tgttttgtttgacagccatga & tctgttatatttaattccagagaagga & 187 \\
\hline Exon $17-2$ & attcagatgcctcgatttgg & tgccttgggaaatactgtgtc & 199 \\
\hline Exon 18 & ccettcccettctcacattt & tccattaagtgaagggaagctc & 166 \\
\hline Exon 19-1 & ttgaactcctgacctcgtga & gcagagaacagcaaataactcca & 195 \\
\hline Exon $19-2$ & cccaaagacttacccgactg & gcagaagaaaggcgttttca & 190 \\
\hline Exon $20-1$ & tcactggcaaaagggtttaga & gcatcacaaagcagtcttcg & 200 \\
\hline Exon 20-2 & tctggaagacctgcattcct & acagaactgccagctcgaat & 191 \\
\hline
\end{tabular}




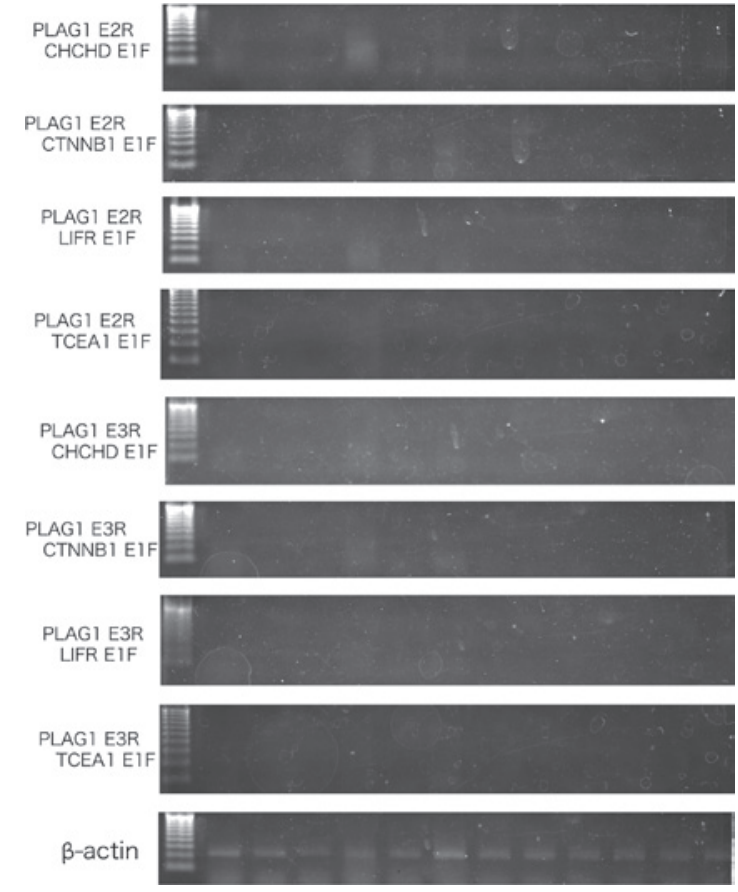

Figure 1. Representative results of RT-PCR. Eight primer pairs were tested for the presence of fusion transcripts involving PLAG1. No product was identified in each primer pair. In the bottom panel, note the products for $\beta$-actin, indicative of successful RNA extraction and reverse transcription. RT-PCR, reverse-transcription PCR; PLAG1, pleiomorphic adenoma gene 1; CHCHD, coiled-coil-helix-coiled-coil-helix domain; $C T N N B 1$, catenin $\beta 1$; $L I F R$, leukemia inhibitory factor receptor $\alpha ; T C E A 1$, transcription elongation factor A (SII), 1 .

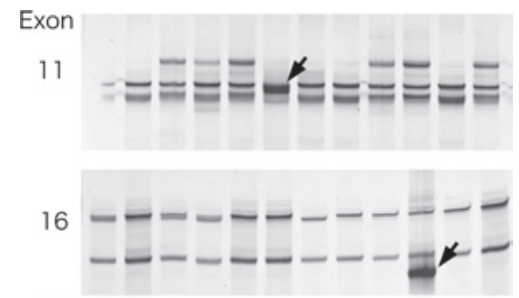

Figure 2. Results of SSCP analysis for exons 11 and 16 of $C Y L D$. The aberrant band is indicated by arrows. These products were subjected to DNA sequencing. SSCP, single strand conformational polymorphism; CYLD, cylindromatosis.

(TCEAI) were analyzed. The sequence data of the primers is presented in Table I. The primer sequences were those reported by Matsuyama et al (9). PCR was performed using 2.5 units Taq DNA polymerase (AmpliTaq Gold; Perkin Elmer, Norwalk, CT, USA), $1.5 \mathrm{mmol} / 1 \mathrm{MgCl}_{2}$, PCR buffer (Perkin Elmer), $200 \mu \mathrm{mol} / 1$ each DNP (Perkin Elmer) and $0.2 \mu \mathrm{mol}$ forward and reverse primers. The 35 -cycle PCR amplification consisted of 35 cycles of denaturation at $94^{\circ} \mathrm{C}$ for $30 \mathrm{sec}$, annealing at $59^{\circ} \mathrm{C}$ for $30 \mathrm{sec}$ and elongation at $72^{\circ} \mathrm{C}$ for $30 \mathrm{sec}$, followed by a final extension at $72^{\circ} \mathrm{C}$ for $10 \mathrm{~min}$.

PCR-single strand conformational polymorphism (SSCP) direct sequencing. Tumor cells were purified from the specimen by laser micro-dissection (LMD) using the Leica LMD system (Leica Microsystems, Wetzlar, Germany). In brief, FFPE specimens were sectioned at $10-\mu \mathrm{m}$ thickness and placed on

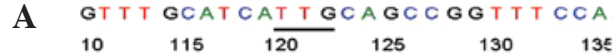
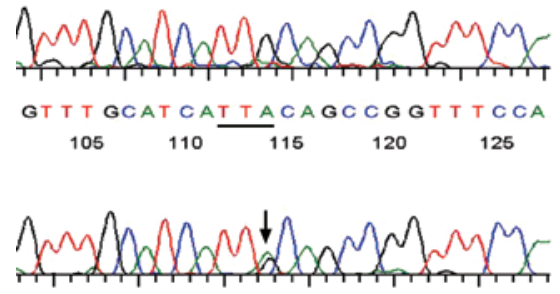

B
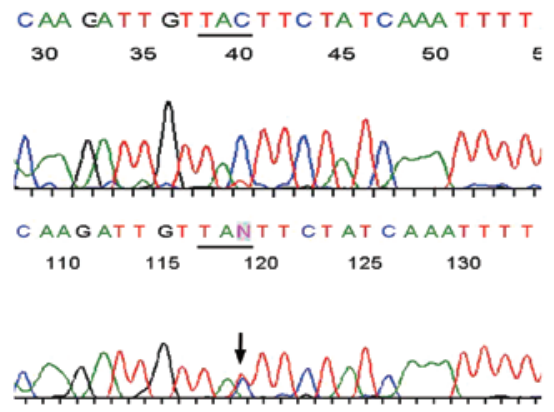

Figure 3. Results of sequence analysis of exons (A) 11 and (B) 16 of CYLD in the samples presented in Fig. 2. (A) Guanine, the 3rd nucleotide of codon 548, is substituted with adenine. (B) Cytosine, the 3rd nucleotide of codon 713 , is substituted with thymine. These point mutations are not associated with amino acid substitutions. The exon and codon numbers were obtained from the Reference Sequence (reference nos. NG_012061.1 and NM_015247.2). $C Y L D$, cylindromatosis.

membrane slides (Leica Microsystems). Following staining with toluidine blue, tumor cells were selected and dissected out using a laser beam under a microscope. Care was paid to avoid contamination by normal tissue surrounding the ACC cells. The dissected tumor cells were digested with proteinase $\mathrm{K}$ and DNA was purified using the DNeasy tissue kit (Qiagen) according to the manufacturer's instructions. The primers for amplification of the $C Y L D$ gene coding exons were designed using Primer 3 (http://primer3.sourceforge.net/webif.php). Table II lists the sequence data of the primers. PCR was performed in $25-\mu 1$ sample volumes as follows: $5 \mathrm{~min}$ at $95^{\circ} \mathrm{C}$ followed by 35 cycles of $30 \mathrm{sec}$ at $95^{\circ} \mathrm{C}, 30 \mathrm{sec}$ at $64^{\circ} \mathrm{C}$ and $30 \mathrm{sec}$ at $72^{\circ} \mathrm{C}$. For SSCP analysis, the PCR products were denatured by heating in a solution of 50\% formamide and $10 \mathrm{mM}$ ethylenediaminetetraacetic acid and then separated on a $12.5 \%$ polyacrylamide gel using the Genephore system (Amersham Pharmacia, Uppsala, Sweden). Following denaturation, single-stranded DNA underwent 3-dimensional folding and assumed a unique conformational state based on the base sequence. The majority of single base changes are detected as mobility shifts (12). The gels were silver stained using a kit (Amersham Pharmacia) to detect the mobility shifts. Mutational analysis was performed for cases demonstrating gene aberration as determined by SSCP. Purified PCR products from ACC and normal tissue adjacent to the tumor were directly sequenced using the BigDye Terminator Cycle sequencing Ready Reaction mix and ABI310 genetic analyzer (both Applied Biosystems, Foster City, CA, USA).

\section{Results}

Representative RT-PCR results are presented in Fig. 1. The $\beta$-actin product was detected in each case. RT-PCR products 
for fusion genes, involving PLAGl, were not obtained at the expected sizes.

Since 35 primer pairs were prepared, a total of 1,190 PCR analyses were performed to examine the coding region of CYLD in the 34 cases of ACC. PCR products were obtained in $\sim 75 \%$ of the PCR analyses. The results of PCR-SSCP analysis are presented in Fig. 2 and aberrant bands are indicated by arrows. These PCR products were subjected to direct sequencing.

Fig. 3 presents results of direct sequencing. The sample with an aberration in exon 11, identified by SSCP analysis, (Fig. 2A) was found to exhibit a silent mutation at codon 548 . The sample with an aberration in exon 16 (Fig. 2B) was also identified to have a silent mutation, located at codon 713 .

\section{Discussion}

It is well known that c-KIT, a proto-oncogene and therapeutic target, is recurrently expressed in ACC $(14,15)$. A previous study reported that the chromosomal translocation $\mathrm{t}(6 ; 9)$, which is associated with overexpression of MYB, is frequently found in ACC (16). Thus, knowledge of the molecular pathology of ACC is increasing, however, the molecular features of ACC remain to be elucidated. In the current study, gene-fusion involving PLAG1 and the mutational status of $C Y L D$ were investigated.

PLAG1, encoding a zinc finger protein, is consistently rearranged in PAs of the salivary glands. Through chromosomal translocation, abnormal expression of PLAG1 is driven by a constitutionally active promoter. Overexpression of PLAG1, acting as a transcription factor, causes deregulation of a variety of PLAG1 target genes. The aberrant expression of these target genes is hypothesized to be the cause of PA (17). Aberrations in PLAG1 have been detected in neoplasms other than PA. Chromosomal rearrangement involving PLAGl are present in the majority of lipoblastomas $(18,19)$. Although the fusion partner for PLAG1 varies, PLAG1 with a strong promoter following chromosomal rearrangement has been identified in lipoblastoma as well as PA (19). Thus, aberrant expression of PLAG1 occurs in these neoplasms, acting as an oncogene. In the present study, the gene fusions of PLAGl and several fusion partners, specifically, CTNNB1, CHCHD7, LIFR and $T C E A 1$, were analyzed. These gene fusions have been detected in PA (9). Based on the results of RT-PCR, no gene fusion involving PLAGl was detected in ACC. These results are consistent with observations reported by Matsuyama et al (9). ACC and PA have similar histogenetic properties (8), however, the karyotypical aberrations differ from each other $(20,21)$. In this study, chromosomal abnormalities of ACC were not tested, however, gene fusion, including PLAG1, was investigated in a relatively large number of cases. Results indicate that the mechanism involved in the tumorigenesis of ACC is different from that of PA.

Since cylindroma is a cutaneous neoplasm, cylindroma and ACC do not share histogenetic characteristics, however, myoepithelial cells participate in tumor formation in both types of neoplasms (22). Thus, cylindroma and ACC share morphological characteristics. $C Y L D$, encoding a deubiquitinating enzyme, is associated with cylindromatosis, multiple familial trichoepithelioma and Brooke-Spiegler syndrome (10). In addition to these tumors, loss of CYLD expression is observed in various types of skin cancer, including basal cell and squamous cell carcinoma (23). Choi et al (24) identified loss of heterozygosity at the CYLD locus in basal cell adenoma of the salivary gland. Thus, $C Y L D$ may play a role in tumorigenesis in various neoplasms.

In the present study, the mutational status of $C Y L D$ was investigated in ACC. A silent mutation was detected in only two cases, indicating that CYLD does not play a role in ACC tumorigenesis comparable to that in Brooke-Spiegler syndrome.

In the present study, no gene fusions of PLAG1 or mutations of $C Y L D$ were identified, indicating that these genes are not involved in ACC tumorigenesis.

\section{References}

1. Asp J, Persson F, Kost-Alimova M and Stenman G: CHCHD7-PLAG1 and TCEA1-PLAG1 gene fusions resulting from cryptic, intrachromosomal 8q rearrangements in pleomorphic salivary gland adenomas. Genes Chromosomes Cancer 45: 820-828, 2006.

2. Aström AK, Voz ML, Kas K, Röijer E, Wedell B, Mandahl N, Van de Ven W, Mark J and Stenman G: Conserved mechanism of PLAG1 activation in salivary gland tumors with and without chromosome 8q12 abnormalities: identification of SII as a new fusion partner gene. Cancer Res 59: 918-923, 1999.

3. Martins C, Fonseca I, Roque L, Pereira T, Ribeiro C, Bullerdiek J and Soares J: PLAG1 gene alterations in salivary gland pleomorphic adenoma and carcinoma ex-pleomorphic adenoma: a combined study using chromosome banding, in situ hybridization and immunocy tochemistry. Mod Pathol 18: 1048-1055, 2005.

4. Kas K, Voz ML, Röijer E, Aström AK, Meyen E, Stenman G and Van de Ven WJ: Promoter swapping between the genes for a novel zinc finger protein and beta-catenin in pleiomorphic adenomas with $\mathrm{t}(3 ; 8)(\mathrm{p} 21 ; \mathrm{q} 12)$ translocations. Nat Genet 15: 170-174, 1997.

5. Voz ML,Aström AK, Kas K, Mark J, Stenman G and Van de Ven WJ: The recurrent translocation $\mathrm{t}(5 ; 8)(\mathrm{p} 13 ; \mathrm{q} 12)$ in pleomorphic adenomas results in upregulation of PLAG1 gene expression under control of the LIFR promoter. Oncogene 16: 1409-1416, 1998.

6. Bullerdiek J, Wobst G, Meyer-Bolte K, Chilla R, Haubrich J, Thode B and Bartnitzke S: Cytogenetic subtyping of 220 salivary gland pleomorphic adenomas: correlation to occurrence, histological subtype and in vitro cellular behavior. Cancer Genet Cytogenet 65: 27-31, 1993.

7. Mark J, Dahlenfors R and Wedell B: Impact of the in vitro technique used on the cytogenetic patterns in pleomorphic adenomas. Cancer Genet Cytogenet 95: 9-15, 1997.

8. Orenstein JM, Dardick I and van Nostrand AW: Ultrastructural similarities of adenoid cystic carcinoma and pleomorphic adenoma. Histopathology 9: 623-638, 1985.

9. Matsuyama A, Hisaoka M, Nagao Y and Hashimoto H: Aberrant PLAG1 expression in pleomorphic adenomas of the salivary gland: a molecular genetic and immunohistochemical study. Virchows Arch 458: 583-592, 2011.

10. Bignell GR, Warren W, Seal S, et al: Identification of the familial cylindromatosis tumour-suppressor gene. Nat Genet 25: 160-165, 2000.

11. Massoumi R: CYLD: a deubiquitination enzyme with multiple roles in cancer. Future Oncol 7: 285-297, 2011.

12. Ellis GL and Auclair PL: Adenoid cystic carcinoma. In: Tumors of the Salivary Glands. Rosai J and Sobin LH (eds). Armed Forces Institute of Pathology, Washington D.C., pp203-216, 1996.

13. Orita M, Iwahana H, Kanazawa H, Hayashi K and Sekiya T: Detection of polymorphisms of human DNA by gel electrophoresis as single-strand conformation polymorphisms. Proc Natl Acad Sci USA 86: 2766-2770, 1989.

14. Holst VA, Marshall CE, Moskaluk CA and Frierson HF Jr: KIT protein expression and analysis of c-kit gene mutation in adenoid cystic carcinoma. Mod Pathol 12: 956-960, 1999.

15. Jeng YM, Lin CY and Hsu HC: Expression of the c-kit protein is associated with certain subtypes of salivary gland carcinoma. Cancer Lett 154: 107-111, 2000. 
16. Persson M, Andrén Y, Mark J, Horlings HM, Persson F and Stenman G: Recurrent fusion of MYB and NFIB transcription factor genes in carcinomas of the breast and head and neck. Proc Natl Acad Sci USA 106: 18740-18744, 2009.

17. Van Dyck F, Declercq J, Braem CV and Van de Ven WJ: PLAG1, the prototype of the PLAG gene family: versatility in tumour development (review). Int J Oncol 30: 765-774, 2007.

18. Astrom A, D'Amore ES, Sainati L, Panarello C, Morerio C, Mark J and Stenman G: Evidence of involvement of the PLAG1 gene in lipoblastomas. Int J Oncol 16: 1107-1110, 2000.

19. Hibbard MK, Kozakewich HP, Dal Cin P, Sciot R, Tan X, Xiao S and Fletcher JA: PLAG1 fusion oncogenes in lipoblastoma. Cancer Res 60: 4869-4872,2000.

20. Nordkvist A, Mark J, Gustafsson H, Bang G and Stenman G: Non-random chromosome rearrangements in adenoid cystic carcinoma of the salivary glands. Genes Chromosomes Cancer 10: 115-121, 1994.
21. Jin C, Martins C, Jin Y, et al: Characterization of chromosome aberrations in salivary gland tumors by FISH, including multicolor COBRA-FISH. Genes Chromosomes Cancer 30: 161-167, 2001

22. Tellechea O, Reis JP, Ilheu O and Baptista AP: Dermal cylindroma. An immunohistochemical study of thirteen cases. Am J Dermatopathol 17: 260-265, 1995.

23. Masoumi KC, Shaw-Hallgren G and Massoumi R: Tumor suppressor function of CYLD in nonmelanoma skin cancer. J Skin Cancer 2011: 614097, 2011.

24. Choi HR, Batsakis JG, Callender DL, Prieto VG, Luna MA and El-Naggar AK: Molecular analysis of chromosome 16q regions in dermal analogue tumors of salivary glands: a genetic link to dermal cylindroma? Am J Surg Pathol 26: 778-783, 2002. 